\title{
Neospora caninum as causative agent of ovine encephalitis in Iran
}

\author{
Farhang Sasani ${ }^{1 *}$, Javad Javanbakht ${ }^{1}$, Parvaneh Seifori ${ }^{2}$, Saeid Fathi ${ }^{3}$ and Mehdi Aghamohammad Hassan ${ }^{4}$ \\ *Correspondence: Fsasani@ut.ac.ir \\ 'Department of Pathology, Faculty of Veterinary Medicine, Tehran University, Tehran, Iran. \\ ${ }^{2}$ Department of Pathology, Veterinary organization of Iran, Tehran, Iran. \\ ${ }^{3}$ Department of Parasitology, Faculty of Veterinary Medicine, Tehran University, Tehran, Iran. \\ ${ }^{4}$ Department of Clinical Sciences, Faculty of Veterinary Medicine, Tehran University, Tehran, Iran.
}

\begin{abstract}
Background: Neospora caninum, an apicomplexan parasite closely related to Toxoplasma gondii, causes abortion, stillbirths, and congenital neurologic disease in multiple animal species. The principle method of diagnosing $N$. caninum infection in aborted fetuses is by histopathology (HP) of fetal tissues. A sensitive and specific PCR detection assay for N. caninum DNA would be useful to augment the diagnosis of $N$. caninum abortion where pathologic changes in fetal tissues are consistent with neosporosis. The aim of this study was to investigate the presence of the encephalitis with focal and multifocal brain lesions that induced N.caninum abortion in sheep.

Methods: During 2004 to 2008, 109 aborted fetus's brains of sheep were collected to identify the possible causes of abortion from different provinces of Iran and were investigated in the pathology laboratory. Foetal histopathology was used to detect the presence of protozoal-associated lesions in brain. The presence of N. caninum was confirmed by Semi-nested PCR.

Results: Histopathological examination of this case demonstrated extensive suppurative and nonsuppurative meningoencephalitis, suppurative meningitis and non-septic and septic encephalitis. Along with various lesions incidence of cellular and vascular, the glial reactions were also assessed in aborted fetal brain tissues containing gliosis (focal or diffuse).During the process of extracting DNA from 109 selected samples, DNA extracted only in one case by semi-nested PCR test was positive for the presence of N.caninum.

Conclusions: This study demonstrates that $N$. caninum can be agent of brain lesions in sheep. This is the first report of $N$. caninum in sheep from Iran that indicated encephalitis brain lesion in hemispheres of the brain cortex.
\end{abstract}

Keywords: Neospora caninum, semi-nested PCR, histopathological, sheep, abortion

\section{Introduction}

Neospora caninum is phenotypically and phylogenetically closely related cyst-forming coccidian or apicomplexan parasites, identified as significant causes of reproductive failure in cattle and small ruminants [1]. N. caninum is a major pathogen for cattle and dogs and it occasionally causes clinical infections in horses, goats, sheep, and deer. Research reports of clinical manifestations of $N$. caninum in sheep is limited to a fatal congenital neosporosis in a newborn lamb [2], and a ewe and her two fetuses [3]. N. caninum was first diagnosed in a congenitally-infected lamb in England, [4]. Historically, this was the first record of $\mathrm{N}$. caninum-like infection in a ruminant [5]. Subsequently, Kobayashi et al., (2001) reported cases of natural infection by $N$. caninum in sheep fetuses, indicating vertical transmission. Hassig et al., (2003) reported the first association between $N$. caninum and abortion in naturally infected sheep through polymerase chain reaction (PCR) in the brain of four fetuses from a flock with frequent abortions [6]. Recently, an association between N. caninum infection and abortion in sheep within New Zealand has been suggested [7].

In addition to,Bishop et al., (2010) reported the most severe neurological lesions such as acute non-suppurative meningoencephalitis and mild to moderate non-suppurative myelitis in ovine cerebral neosporosis [8]. Luı's et al., (2001) have been reported distinguishing features in goat kid included neurologic impairment resulting from congenital infection with $N$. caninum and the presence of granulomatous inflammation with rare giant cells associated with degeneration of tissue cysts [9]. The present study is the first report of abortion associated with N. caninum agent in Iran's sheep.

\section{Materials and methods \\ Sample collection}

During 2004 to 2008, 109 aborted fetus's brains of sheep from different provinces were collected to identify the possible causes of abortion and were investigated in the pathology laboratory. The number of samples have been related to the abortion problem in the provinces, interest rate of provincial experts and pursuit of ranchers. Microbiology test directory containing all tests for bacteriology (C. abortus, Coxiella burnetti , Leptospira spp., B. melitensis, Campylobacter spp., Salmonella abortus and atc), serology, virology (Border disease,Bluetongue,Akabane and atc) and others were analysed by provincial experts that certain results have not been achieved from those tests. In fact, 


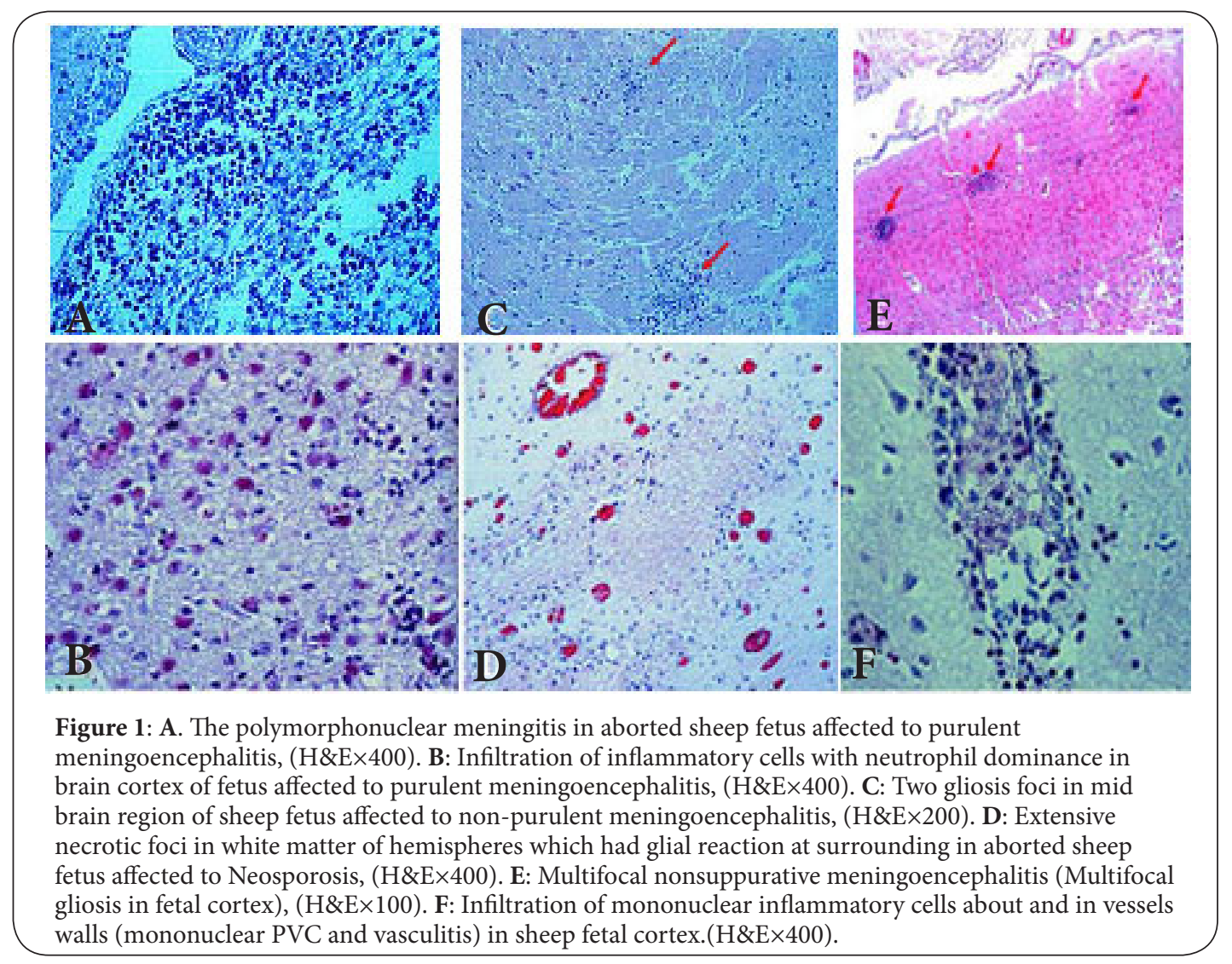

those samples were negative for for bacteriology serology, virology and all foetuses were obtained from abortion cases that took place on farms in different areas of Iran.

The samples with the highest frequency were submitted from Kurdistan province of Mazandaran, Tehran, Yazd, Ardabil, Markazi, Kerman, Hamedan, western Azerbaijan, Khuzestan, Fars and Isfahan, respectively. Most of ovine aborted fetus's brains have been sent from Tehran and Mazandaran province (Figure 3).

All specimens of ovine aborted fetuses' brain which no specific bacterium was isolated through initial bacteriological assessment in provinces' centers, were collected and referred to pathological lab of Veterinary Reference Department. A complete necropsy was performed on all foetuses submitted (109 aborted fetus's brains), and the presence of macroscopic lesions was also evaluated. Samples were fixed in containers contained formalin $10 \%$ and transverse slices were performed from fixed brain tissues in regions as frontal lobes, thalamic nuclei, optic chiasma, occipital lobe, hippocampus and midbrain of cranial geniculates, pike brain and cerebellum.

\section{Histopathological analysis}

For the histopathological study, fixed brain tissues of 109 aborted fetus's brains were dehydrated through graded alcohols before being embedded in paraffin wax using routine procedures. Blocks were cut in $4 \mu \mathrm{m}$ sections, deparaffinized, rehydrated, stained with hematoxylin and eosin (H\&E) and examined by light microscopy. Brains were examined for protozoal-associated lesions and microscopic examination was done on the different parts of brains.

\section{DNA extraction}

DNA extraction was performed on paraffin embedded, formalin fixed brain tissues of all brain sections. After several freezing and thawing cycles, between 5 and $10 \mathrm{~g}$ of each brain sample (of all brain sections recovered at necropsy and depending on the quantity available) was homogenized in a Potter Homogenizer and stored at $-20^{\circ} \mathrm{C}$. Nested PCR was performed on all samples to detect $N$. caninum. For $N$. caninum, DNA extraction was performed with the Qiagen DNA Mini Kit (Qiagen, Venlo, The Netherlands), using a slightly modified protocol: to $400 \mu \mathrm{l}$ of homogenized brain sample, $40 \mu \mathrm{l}$ of proteinase $\mathrm{K}$ and $400 \mu \mathrm{l}$ AL lysis buffer were added and incubated at $56^{\circ} \mathrm{C}$ until complete lysis $(0.32$ Msucrose, 0.01 MTris, $0.44 \mathrm{M} \mathrm{NaCl}, 1 \%$ Triton X-100, and pH 7.5). Then $400 \mu \mathrm{l}$ of a 24/1 mixture of chloroform and iso-amyl-alcohol was added. This was mixed and centrifuged at $22,000 \times \mathrm{g}\left(4^{\circ} \mathrm{C}\right)$ for $20 \mathrm{~min}$. The supernatant was transferred to a new $1.5 \mathrm{ml}$ micro tube and mixed with $200 \mu \mathrm{l}$ of $95+\%$ ethanol to precipitate the DNA. From here on the manufacturer's instructions were 


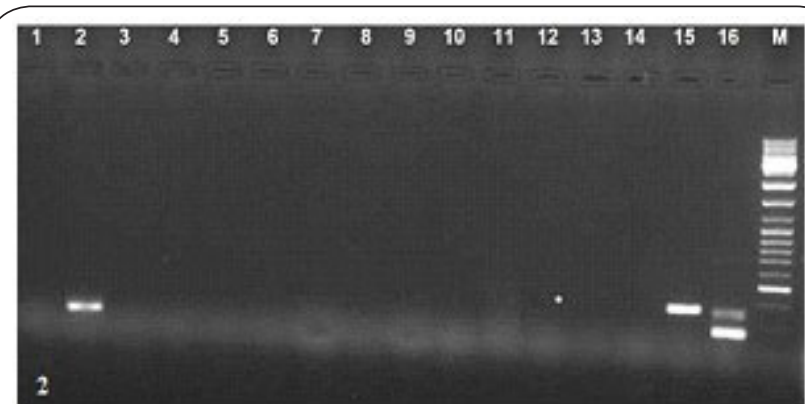

Figure 2. Nested-PCR for Neospora caninum

2-N. caninum positive

14-negative control

15-positive control (N. caninum), in the first step of Nested-PCR

16-positive control (N. caninum), in the Second step of Nested-PCR

M-Size marker(100 bp DNA Ladder).

followed: the lysate /ethanol mixture was transferred to a spin column, washed once with $500 \mu \mathrm{l}$ AW1 buffer and once with $500 \mu \mathrm{l}$ AW2 buffer. DNA concentrations were determined by spectrophotometric analysis at A141/970, and all samples were diluted to a final concentration of $60 \mathrm{ng} / \mu \mathrm{l}$. The DNA was eluted in $200 \mu \mathrm{l} A \mathrm{E}$ buffer and stored at $-20^{\circ} \mathrm{C}$ till further use (Prior to PCR analysis) [10].

\section{PCR detection of $N$. caninum Semi-nested PCR}

Oligonucleotide primers for N. caninum ITS1 and 18S rRNA sequence (GenBank accession no. AY463245) were designed to amplify a $357 \mathrm{bp}$ DNA fragment. The N. caninum Nc1 forward primer spans nucleotides 111 to 129(5'- AGC GTG ATA TAC TAC TCC C $\left.-3^{\prime}\right)$, Nc2 reverse primer spans nucleotides 446 to 467 (5'- CGA GCC AAG ACA TCC ATT GCT G -3') and Nc3 seminested PCR primer spans nucleotides 209 to 227 (5' GTG TGT GCA TAT ATC CGG G 3') (Figure 1). The PCR mixture of $50 \mu \mathrm{l}$ contained $0.1-1.0 \mu \mathrm{g}$ of target DNA, $2 \mathrm{mM} \mathrm{MgCl}_{2}$, $10 \times$ reaction buffer $(50 \mathrm{mM} \mathrm{KCl}, 10 \mathrm{mM}$ Tris- $\mathrm{HCl}$ [pH8.3], 10 pmol of each PCR primer, $200 \mu \mathrm{M}$ each dNTP, and $1 \mathrm{U}$ of Taq DNA polymerase (Cinna Gen, Iran). PCRs were performed in a thermocycler (Techgene-Techne, Germany) for 35cyclesof denaturation at $94^{\circ} \mathrm{C}$ for $30 \mathrm{~S}$, annealing at $55^{\circ} \mathrm{C}$ for $45 \mathrm{~S}$, and extension at $72^{\circ} \mathrm{C}$ for $60 \mathrm{~S}$. For semi-nested PCR, second-round primers Nc2 and Nc3were used $2 \mu$ l of amplicon solution from first-round Nc1-Nc2 PCR amplification as target DNA with the same PCR mixture subjected to $35 \mathrm{cycles}$ of denaturation at $94^{\circ} \mathrm{C}$ for $30 \mathrm{~S}$ annealing at $55^{\circ} \mathrm{C}$ for $45 \mathrm{~S}$, and extension at $72^{\circ} \mathrm{C}$ for $60 \mathrm{~S}$. Amplicons were resolved on a $2 \%$ agarose gel stained with ethidium bromide and photographed under UV light. Positive controls (purified N. caninum) and negative controls (doubledistilled water) were included in each set of PCR reactions. Positive sample was tested at least three times for showing

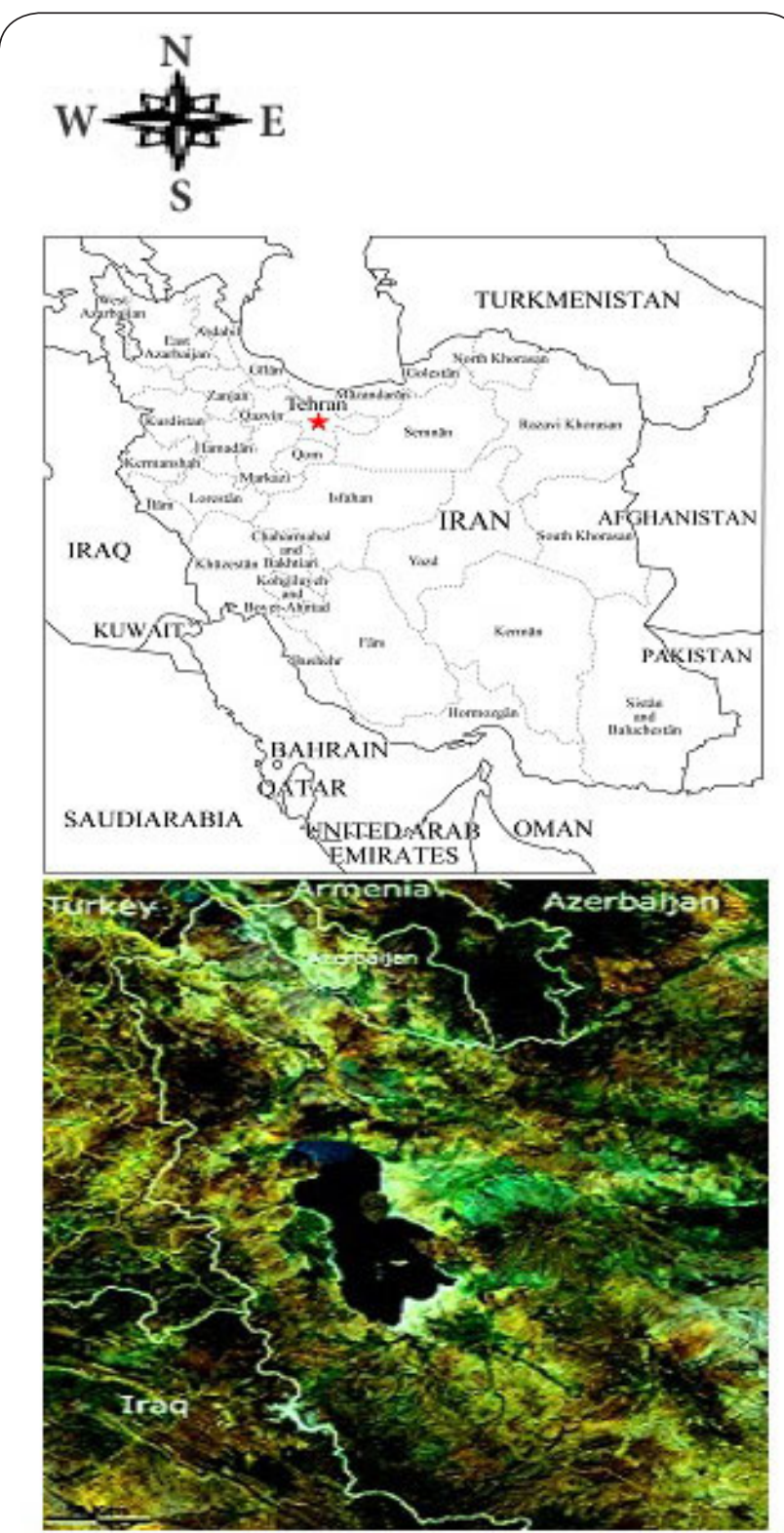

Figure 3. Satellite image of the study area of provinces of Iran (source: Google Map).

reproducibility of the specific PCR. Amplification products were analyzed by electrophoresis through a $2 \%$ agarose gel for the specific N. caninum PCR [11].

\section{Results}

Paraffin blocks containing the lesion and parasite sections cysts were used for Semi-nested PCR based on indicator of cysts for detecting protozoan encephalitis including multi focal gliosis and necrosis, necrogranuloma. During the process of extracting DNA from 109selected samples, DNA extracted from only one case. Semi-nested PCR test was positive for the 
Sasani et al. Pathology Discovery 2013,

presence of N. caninum. (Figure 2).

In this research the observed lesions were assessed based on various fetal brain histoanatomies and presence of the histopathologic findings of the inflammation in nervous system such as PVC, gliosis, necrosis and inflammation. Those were determined according to presence of at least one of the prominent features of inflammation in various regions of the brain, including hemispheres (cortex and white matter), midbrain, medulla oblongata and cerebellum affected to inflammatory reactions. The most inflammatory lesions were in brain cortex, medulla oblongata, midbrain, white matter of hemispheres and cerebellum.

Significant lesions in the hemispheres of the brain cortex were detected. Lesions including multifocal necrosis and multifocal gliosis were observed in the hemispheres of the brain cortex.

Patterns of brain damage that observed in this study including encephalitis (Septic and non-septic), including extensive nonsuppurative and suppurative meningoencephalitis, non-septic and septic encephalitis and suppurative meningitis (Figure 1A-1D). Along with various lesions incidence of cellular and vascular, the glial reactions were also assessed in aborted fetal brain tissues containing gliosis (focal or diffuse), glial nodules and satellitosis, In histopoathological evaluation, on aborted fetal brain, the necrotic reactions in neurons and glial were ascertained as multifocal necrosis, degenerative changes, scattered neuronal individual necrosis (neuronal chromatolysis and ischemic alterations) (Figure 1D-1F).

\section{Discussion}

Neosporosis in sheep that are intermediate hosts of $N$. caninum is inadequately studied. Sheep could be infected per os with N. caninum [12]. Pregnant sheep are very susceptible to experimental infection with $N$. caninum tachyzoites [13-19].

Furthermore, in this research indicated that sample contained multifocal cerebral cortex, and incidence of multifocal necrosis in white mater occurred next to multifocal necrotic encephalitis; however, determining whether this lesions occurred through specific parasitic pathogenesis or hypoxia due to placental damage more precise evaluation and utilizing of newly methods as immunohistochemistry, in situ-PCR to parasitic antigen detection is required.

PCR analysis of the brains with lesions observed that one sample was positive for $N$. caninum DNA. This result was not surprising as previous studies in the Iran also have no reported positive PCR results with DNA extracted from the ovine brain fetuses.

In a study in Switzerland following abortion incidence in a sheep flock by Hassig et al., (2003) indicated through PCR of 20 aborted fetuses, 4 cases were positive for Neosporosis which the histopathological lesions were manifested as well [6].

In this study, the fetal brain samples of histopathological lesions related to protozoal encephalitis including multifocal necrotic meningoencephalitis were undergone semi-nested
PCR to detect $N$. caninum DNA, with the exception of one case, all samples were negative. The positive specimens associated with aborted fetuses were in two one-third stage of pregnancy. The histopathology lesions including multiple extensive necrotic foci in hemispheres of the brain cortex were observed which surrounded by glial, inflammatory mononuclear and gitter cells. Georgieva et al., 2006 have been reported $N$. caninum in abort dead lambs 25-30 days after the infection that lesions in different part of brain were observed20. An encephalitis characterized by multiple foci, hemorrhages and necroses was found out. In a study Kobayashi et al., (2001) discovered a natural neosporosis in a pregnant sheep and its twin foetuses. A focal encephalitis and thick wall tissue cysts of $N$. caninum were present in sheep. N. caninum was also isolated by Koyama et al., (2001) from another lambed sheep [20].

Also in this study, in pathological assessment of the brain, the multifocal gliosis, mononuclear PVC, multiple and scattered glial nodules, severe hyperemia and focal hemorrhages, thrombus in cerebral vessels and meningitis accompanying infiltration of inflammatory cells such as lymphocyte, monocyte and neutrophils were observed. Findings of this study are in agreement with findings of Bishop et al., (2010) that observed non-suppurative meningoencephalitis and non-suppurative encephalitis in sheep.

On histopathological study of Neosporosis in goat by Moor et al., (2005) revealed non-purulent encephalitis with infiltration foci of mononuclear inflammatory cells and microgliosis, lymphocytic and plasmocytic PVC and granulomatous inflammation in necrosis region of aborted goats' fetus brains [21].

Futhermore, Lui's et al., (2001) have been reported multinucleate giant cells adjacent to inflammatory foci by $N$. caninum in brain of goat kid [9]. Histopathological lesions of widespread necrotizing encephalomyelitis and meningitis have been recorded incongenital $N$. caninum infection in bovines [22] and in experimental adult mice [23] and In a study in Switzerland following abortion incidence in a sheep flock by Hassig et al., (2003) indicated through PCR of 20 aborted fetuses, 4 cases were positive for Neosporosis which the histopathological lesions were manifested as well.

In conclusions, the study demonstrates that due to the pasture breeding of Iranian sheep, we expected a higher occurrence of $N$. caninum brain lesions in these animals. Although sheep are experimentally sensitive to $N$. caninum infection, in naturally exposed sheep this infection is an infrequent cause of abortion. On the basis of these results we believe that neosporosis in sheep has significant impact on reproduction with subsequently less economic losses in comparison with cattle.

\section{Competing interests}

The authors declare that they have no competing interests. 
Sasani et al. Pathology Discovery 2013,

\section{Authors' contributions}

\begin{tabular}{|l|l|l|l|l|l|}
\hline Authors' contributions & FS & JJ & PS & SF & MAH \\
\hline Research concept and design & $\sqrt{ }$ & $\sqrt{ }$ & $\sqrt{ }$ & -- & -- \\
\hline Collection and/or assembly of data & -- & -- & -- & $\sqrt{ }$ & $\sqrt{ }$ \\
\hline Data analysis and interpretation & -- & $\sqrt{ }$ & -- & $\sqrt{ }$ & -- \\
\hline Writing the article & $\sqrt{ }$ & $\sqrt{ }$ & -- & $\sqrt{ }$ & $\sqrt{ }$ \\
\hline Critical revision of the article & -- & $\sqrt{ }$ & -- & -- & -- \\
\hline Final approval of article & -- & $\sqrt{ }$ & $\sqrt{ }$ & -- & -- \\
\hline Statistical analysis & $\sqrt{ }$ & -- & -- & -- & $\sqrt{ }$ \\
\hline Other (please specify)................... & $\sqrt{ }$ & $\sqrt{ }$ & $\sqrt{ }$ & $\sqrt{ }$ & $\sqrt{ }$ \\
\hline
\end{tabular}

\section{Acknowledgement}

The authors kindly thank Department Pathology for

sequencing the samples, and technical assistance.

\section{Publication history}

Editor: Hiroko Kuwabara, Osaka Medical College, Japan.

EIC: Markus H. Frank, Harvard Medical School, USA.

Received: 19-Aug-2013 Revised: 23-Aug-2013

Accepted: 02-Sep-2013 Published: 07-Sep-2013

\section{References}

1. Dubey JP. Review of Neospora caninum and neosporosis in animals. Korean J Parasitol. 2003; 41:1-16. | Article | PubMed Abstract | PubMed Full Text

2. Dubey JP and Lindsay DS. Neospora caninum (Apicomplexa) induced abortions in sheep. Journal of Veterinary Diagnostic Investigations. 1990; 2:230-233. | Pdf

3. Kobayashi $\mathrm{Y}$, Yamada M, Omata Y, Koyama T, Saito A, Matsuda T, Okuyama K, Fujimoto S, Furuoka $\mathrm{H}$ and Matsui T. Naturally-occurring Neospora caninum infection in an adult sheep and her twin fetuses. $J$ Parasitol. 2001; 87:434-6. | Article | PubMed

4. Dubey JP, Hartley WJ, Lindsay DS and Topper MJ. Fatal congenital Neospora caninum infection in a lamb. J Parasitol. 1990; 76:127-30. | Article | PubMed

5. Hartley WJ and Bridge PS. A case of suspected congenital Toxoplasma encephalomyelitis in a lamb associated with a spinal cord anomaly. $\mathrm{Br}$ Vet J. 1975; 131:380-4. I PubMed

6. Hassig M, Sager H, Reitt K, Ziegler D, Strabel D and Gottstein B. Neospora caninum in sheep: a herd case report. Vet Parasitol. 2003; 117:213-20. | Article | PubMed

7. Howe L, West DM, Collet MG, Tattersfield G, Pattison RS and Pomroy WE. The role of Neospora caninum in three cases of nexplained ewe abortions in the southern North Island of New Zealand. Small Ruminant Research. 2008; 75:115-122. | Article

8. Bishop S, King J, Windsor P, Reichel MP, Ellis J and Slapeta J. The first report of ovine cerebral neosporosis and evaluation of Neospora caninum prevalence in sheep in New South Wales. Vet Parasitol. 2010; 170:137-42. | Article | PubMed

9. Corbellini LG, Colodel EM and Driemeier D. Granulomatous encephalitis in a neurologically impaired goat kid associated with degeneration of Neospora caninum tissue cysts. J Vet Diagn Invest. 2001; 13:416-9. | Article I PubMed

10. Sambrook J, Fritsch EF, Maniatis T: Molecular cloning: a laboratory manual (2 edn.) Cold Spring Harbor Laboratory Press, Cold Spring Harbor, N.Y, 1989.

11. Sadrebazzaz A, Habibi G, Haddadzadeh H and Ashrafi J. Evaluation of bovine abortion associated with Neospora caninum by different diagnostic techniques in Mashhad, Iran. Parasitol Res. 2007; 100:125760. | Article | PubMed

12. O'Handley R, Liddell S, Parker C, Jenkins MC and Dubey JP. Experimental infection of sheep with Neospora caninum oocysts. J Parasitol. 2002; 88:1120-3. | Article | PubMed

13. McAllister MM, McGuire AM, Jolley WR, Lindsay DS, Trees AJ and
Stobart RH. Experimental neosporosis in pregnant ewes and their offspring. Vet Pathol. 1996; 33:647-55. | Article | PubMed

14. Buxton D, Maley SW, Thomson KM, Trees AJ and Innes EA. Experimental infection of non-pregnant and pregnant sheep with Neospora caninum. J Comp Pathol. 1997; 117:1-16. | Article | PubMed

15. Buxton D, Maley SW, Wright S, Thomson KM, Rae AG and Innes EA. The pathogenesis of experimental neosporosis in pregnant sheep. J Comp Pathol. 1998; 118:267-79. | Article | PubMed

16. Buxton $D$, McAllister MM and Dubey JP. The comparative pathogenesis of neosporosis. Trends Parasitol. 2002; 18:546-52. | Article | PubMed

17. Jolley WR, McAllister MM, McGuire AM and Wills RA. Repetitive abortion in Neospora-infected ewes. Vet Parasitol. 1999; 82:251-7. | Article | PubMed

18. Innes EA, Wright SE, Maley S, Rae A, Schock A, Kirvar E, Bartley P, Hamilton C, Carey IM and Buxton D. Protection against vertical transmission in bovine neosporosis. Int J Parasitol. 2001; 31:1523-34. | Article I PubMed

19. Geordieva DA, Prelezov PN and Koinarski V. Neospora caninum and neosporosis in animals - A review. Bulgarian Journal of Veterinary Medicine. 2006; 9:1-26.

20. Koyama T, Kobayashi Y, Omata Y, Yamada M, Furuoka H, Maeda R, Matsui $T$, Saito $A$ and Mikami T. Isolation of Neospora caninum from the brain of a pregnant sheep. J Parasitol. 2001; 87:1486-8. | Article | PubMed

21. Moore DP. Neosporosis in South America. Vet Parasitol. 2005; 127:87-97. | Article | PubMed

22. Wouda W, Moen AR, Visser IJ and van Knapen F. Bovine fetal neosporosis: a comparison of epizootic and sporadic abortion cases and different age classes with regard to lesion severity and immunohistochemical identification of organisms in brain, heart, and liver. J Vet Diagn Invest. 1997; 9:180-5. | Article | PubMed

23. Atkinson R, Harper PA, Ryce C, Morrison DA and Ellis JT. Comparison of the biological characteristics of two isolates of Neospora caninum. Parasitology. 1999; $118: 363-70$. | Article | PubMed

Citation:

Sasani F, Javanbakht J, Seifori P, Fathi S and Aghamohammad Hassan M. Neospora caninum as causative agent of ovine encephalitis in Iran. Pathol Discov. 2013; 1:5.

http://dx.doi.org/10.7243/2052-7896-1-5 